\title{
Traumatic rupture of sternocleidomastoid muscle following an epileptic seizure
}

\author{
Nicola Rachel Wooles, ${ }^{1}$ Philip Robert Bell, ${ }^{2}$ Marian Korda ${ }^{3}$
}

${ }^{1}$ Department of General Surgery, Craigavon Area Hospital, Portadown, UK ${ }^{2}$ Craigavon Area Hospital, Belfast, UK

${ }^{3}$ Department of ENT, Craigavon Area Hospital, Portadown, UK

\section{Correspondence to} Dr Nicola Rachel Wooles, Nicola.r.wooles.05@aberdeen. ac.uk

Accepted 30 October 2014

\section{SUMMARY}

A 29-year-old man, a known epileptic, presented to an accident and emergency department following a tonicclonic seizure, suffering a second seizure in the department. Subsequently, he reported neck pain, swelling and stiffness. An otorhinolaryngology neck examination revealed a tender left side with two palpable masses and a reduced range of movement. Ultrasound confirmed a ruptured middle third of the left sternocleidomastoid muscle, which was successfully treated non-surgically with analgaesia and intensive physiotherapy. Uncommonly, sternocleidomastoid muscle rupture has been reported following high-velocity trauma, but to the best of our knowledge this is the first case described in the literature following an epileptic seizure.

\section{BACKGROUND}

To the best of our knowledge, this is the first case described in the literature of sternocleidomastoid rupture following an epileptic seizure, and highlights the indispensible importance of a thorough clinical examination.

\section{CASE PRESENTATION}

A 29-year-old man with a history of epilepsy presented to the emergency department following a tonic-clonic seizure lasting approximately $5 \mathrm{~min}$. During the seizure he fell to the ground, striking his head against a window ledge. He subsequently suffered a second short, self-limiting seizure while in the accident and emergency department.

Following these seizures he reported pain, swelling and stiffness on the left side of his neck along with difficulty rotating his head to the right and difficulty lifting it upright as well.

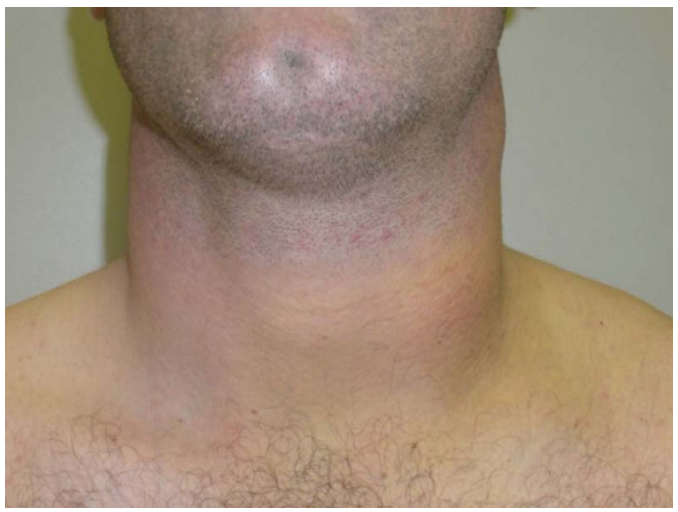

Figure 1 Clinical photograph showing the left-sided neck mass.
On examination by the otolaryngology team his neck was tender on the left side with two palpable masses (figure 1). He was noted to have reduced rotation to the right and lateral flexion to the left side. Neurological examination was normal.

\section{INVESTIGATIONS}

An ultrasound scan was performed, which showed a rupture at the middle third of the left sternocleidomastoid muscle (figure 2).

\section{TREATMENT}

The patient was managed conservatively with simple analgaesia and referred for intensive physiotherapy. When he was reviewed 6 weeks later, following physiotherapy, he was found to have a significant functional improvement; however, a defect in the sternocleidomastoid muscle remained palpable.

Treatment of sternocleidomastoid muscle is primarily conservative with intensive physiotherapy. This must be initiated early as delay may lead to development of torticollis resulting in cosmetic deformity and physical restriction.

If physiotherapy is unsuccessful, a low threshold for consideration of surgical correction such as unipolar release, Z-plasty, transaxillary endoscopic release and muscle resection must be enforced to prevent subsequent restrictive deformities. ${ }^{1}$

\section{DISCUSSION}

Epilepsy is a relatively common condition; however, epilepsy with significant secondary soft tissue injury in the neck is rare, although it has been implicated in case reports of myotendinous rupture of temporalis and carotid artery dissection. $^{23}$

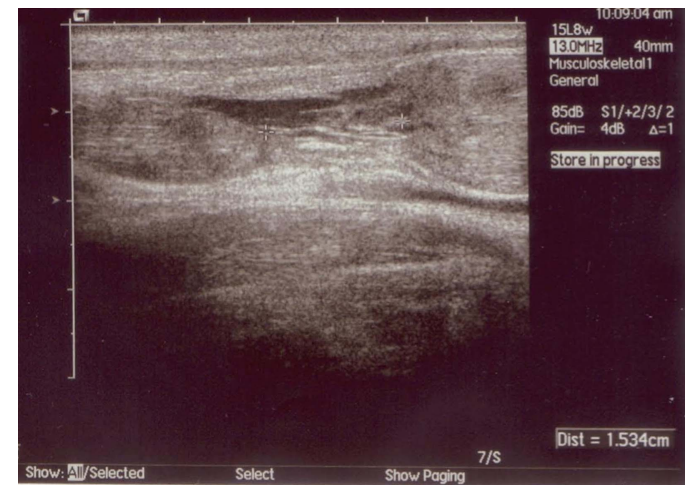

Figure 2 Ultrasound scan showing partial rupture of the left sternocleidomastoid muscle. 
Injury to the neck musculature and cervical spine can occur secondary to hyperextension injuries during any trauma, which may result in cervical spine fracture, muscular spasm or potentially sternocleidomastoid rupture. ${ }^{4}$

Rupture of the sternocleidomastoid muscle is relatively uncommon but has been reported following significant trauma such as in a motor vehicle collision. ${ }^{4}$
Contributors This article was written and edited by NRW and PRB. The process was overseen and guided by MK.

Competing interests None.

Patient consent Obtained.

Provenance and peer review Not commissioned; externally peer reviewed.

\section{Learning points}

- This case demonstrates the importance of a thorough clinical examination to exclude unusual pathology.

- Do not underestimate the impact of physiological trauma on the body.

- Non-surgical interventions in management of acute sternocleidomastoid rupture can be effective.

\section{REFERENCES}

1 Lee IJ, Lim SY, Song HS, et al. Complete tight fibrous band release and resection in congenital muscular torticollis. J Plast Reconstr Aesthet Surg 2010;63: 947-53.

2 Naffa L, Tandon Y, Rubin M. Myotendinous rupture of temporalis muscle: a rare injury following seizure. World J Radiol 2014;6:388-91.

3 Child N, Cascino G. Carotid dissection following a generalized tonic-clonic seizure. Neurology 2013;80:1911.

4 Schuyler-Hacker H, Green R, Wingate L, et al. Acute torticollis secondary to rupture of the sternocleidomastoid. Arch Phys Med Rehabil 1989;70:851-3.

Copyright 2014 BMJ Publishing Group. All rights reserved. For permission to reuse any of this content visit http://group.bmj.com/group/rights-licensing/permissions.

BMJ Case Report Fellows may re-use this article for personal use and teaching without any further permission.

Become a Fellow of BMJ Case Reports today and you can:

- Submit as many cases as you like

- Enjoy fast sympathetic peer review and rapid publication of accepted articles

- Access all the published articles

- Re-use any of the published material for personal use and teaching without further permission

For information on Institutional Fellowships contact consortiasales@bmjgroup.com

Visit casereports.bmj.com for more articles like this and to become a Fellow 